\title{
Anatomical and histochemical comparison of the primary and adventitious roots of Attalea microcarpa (Arecaceae) at the initial growth stage
}

\author{
Marcos Melo CORRÊA ${ }^{1 *}$, Maria Gracimar Pacheco de ARAÚJO², Maria Sílvia de MENDONÇA ${ }^{3}$ \\ Instituto Nacional de Pesquisas da Amazônia - INPA, Programa de Pós-Graduação em Botânica, Manaus, AM, Brasil \\ 2 Universidade Federal do Amazonas - UFAM, Instituto de Ciências Biológicas, Manaus, AM, Brasil \\ 3 Universidade Federal do Amazonas - UFAM, Faculdade de Ciências Agrárias, Manaus, AM, Brasil \\ * Corresponding author: marcos.melo.correa@outlook.com; (D) https://orcid.org/0000-0003-2978-2803
}

\begin{abstract}
We describe the anatomical structure of roots originating from the apocole of Attalea microcarpa compared to the primary root, by means of usual methods for optical microscopy. The adventitious roots are differentiated in the apocole associated to vascular bundles, and can remain as a single structure or branch. They have the basic root structure characteristic of Arecoideae palms, without schizogenous spaces, which are observed in the primary root, in addition to few air spaces. Mucilages, starch and proteins were present in both types of roots. Adventitious roots of the apocole are described for the first time in Arecaceae.
\end{abstract}

KEYWORDS: Amazon, anatomy, germination, palm tree, seedling, root system

\section{Comparação anatômica e histoquímica entre raízes primária e adventícia de Attalea microcarpa (Arecaceae) em estádio inicial de crescimento}

\section{RESUMO}

Este estudo descreve a estrutura anatômica de raízes originárias do apocole de Attalea microcarpa, em comparação à raiz primária por meio de técnicas usuais para microscopia óptica. As raízes adventícias são diferenciadas no apocole, associadas a feixes vasculares, e podem se manter como uma estrutura única ou se ramificar. Possuem a estrutura básica das raízes de palmeiras Arecoideae, com ausência de dutos, que são observados na raiz primária, além de poucos espaços de ar. Mucilagens, amido e proteínas foram detectados em ambos os tipos de raízes. Raízes adventícias da região do apocole são descritas pela primeira vez em Arecaceae.

PALAVRAS-CHAVE: Amazônia, anatomia, germinação, palmeira, plântula, sistema radicular

The root system pattern of palm trees (Arecaceae) has taxonomic importance for the definition of tribes within subfamilies (Karsten 1856; Drabble 1904; Seubert 1997, 1998a,b). Development of the root insertion zone in the root-carrying organs is little known, particularly in tropical palms and in young palm individuals (Tomlinson 1990). The apocole, also called cotyledonary petiole (Tomlinson 1990; Viana et al. 2016), is a portion of the cotyledon that separates the seedling from the seed in palms that have remote germination and is differentiated from the distal region of the embryo (Tillich 2007). Attalea microcarpa Mart. is an underground stem palm, common in lowland forests (Lorenzi 2010), known as palha-vermelha (red straw) (Henderson 1995). Leaves are used as house cover, and mature fruits are consumed by traditional communities (Balslev et al. 2008), and it is similar to Attalea attaleoides (Barb. Rodr.)
Wess. Boer in morphological aspects. The fruit and the seed of the species were studied by Melo et al. 2017, however there are still no records about its establishment and other natural history aspects. Here we describe the anatomy and histochemistry of the primary and adventitious roots of seedlings of Attalea microcarpa, contributing to the knowledge about its ontogeny and recognition at initial seedling stage.

Seedlings of $A$. microcarpa, obtained from a germination experiment in the greenhouse of the Faculty of Agrarian Sciences at Universidade Federal do Amazonas (Manaus, Amazonas, Brazil), were used as material for the anatomical analysis in the elongation phase of the apocole and of the primary root. The seedlings originated from fruits collected in a sustainable development reserve, Reserva de Desenvolvimento Sustentável do Tupé (Manaus, Amazonas, Brazil). The morphological and 
distribution pattern of the coating, supporting and filling tissues and the vascular system arrangement of the roots were characterized by analysing samples from the origin point of the roots in the apocole and the median area of the primary root. Fresh sections of the samples were prepared with a tabletop microtome, clarified with sodium hypochlorite, stained with $1 \%$ Astra blue and 1\% safranin (Safrablau 9:1) (Bukatsch 1972) in aqueous solution and slides were mounted on glycerinated gelatin (Kaiser 1880; Kraus and Arduin 1997). Histochemical tests were performed for the detection of ergastic substances with Lugol (starch), Xilidine Ponceau (proteins), Sudan III (lipids), and tannic acid (mucilages) with fresh material from the median region of the roots. Photomicrographs were obtained by recording with a Canon PC1252 digital camera coupled to a Zeiss Primo Star MicroImaging 37081 photomicroscope.

The development of the root system of $A$. microcarpa presents an adventitious root formation from the apocole in many seedlings in the apocole elongation stage, becoming evident when cataphylls are exposed. (Figure 1). The adventitious roots develop obliquely, associated with parenchymal tissues near vascular bundles of the apocole (Figure 2a,b), and remain as a single structure (Figure 2c) or may branch (Figure 2d,e). In the basal region of these roots the vascular cylinder is relatively undifferentiated, presenting basal-apical differentiation. In the adventitious roots, epidermis is formed by predominantly irregular cells, followed by exodermis of thickened walls, parenchymal cortex in the subepidermal layers with the presence of sclerified cells (Figure 3a,b), and an inner cortex constituted by parenchyma (Figure 3a). Schizogenous spaces do not occur in the cortex (Figure 3c), which are observed in the primary roots. Besides, very few air spaces occur (Figure $3 a)$. The endoderm is sclerified, except in the external celular walls (Figure 3d,e). The pericycle delimits the entire central cylinder, which has 12 vascular bundles around the medulla, which is sclerified with schizogenous spaces (Figure 3e). The bundles occur with protoxylem and phloem bands side by side forming a circle, with the protoxylem in the outermost regions

A B
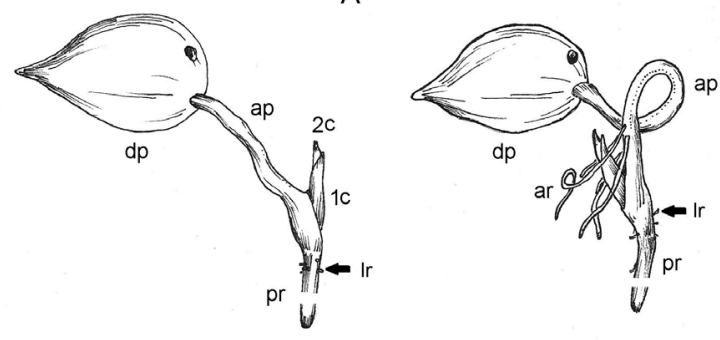

Figure 1. Seedlings of Attalea microcarpa: A) without and B) with adventitious root emission in the apocole. 1c: first cataphyll, 2c: second cataphyll, ap: apocole, ar: adventitious root, dp: diaspore, Ir: lateral root, pr: primary root. Scale bar $=2 \mathrm{~cm}$.
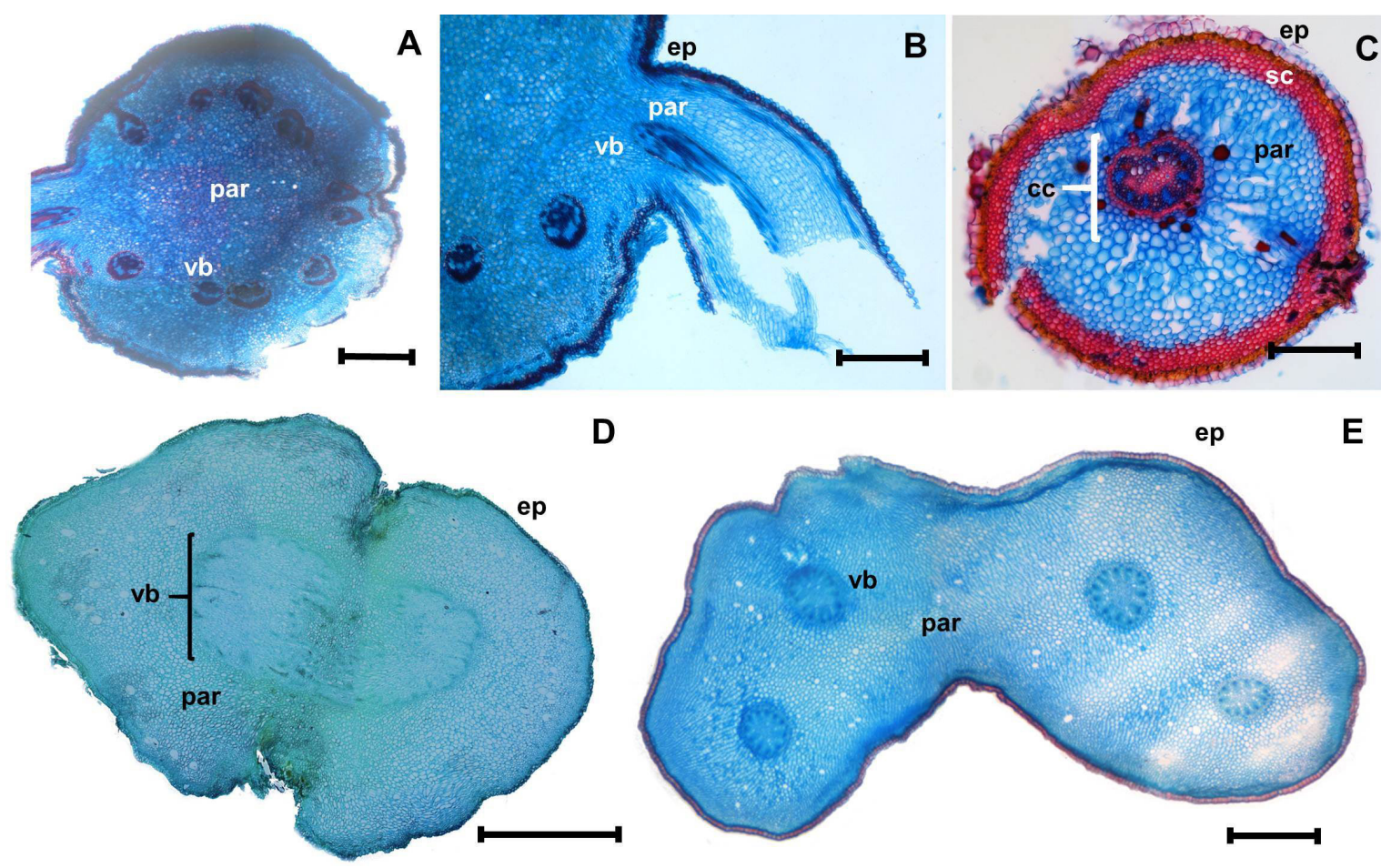

D

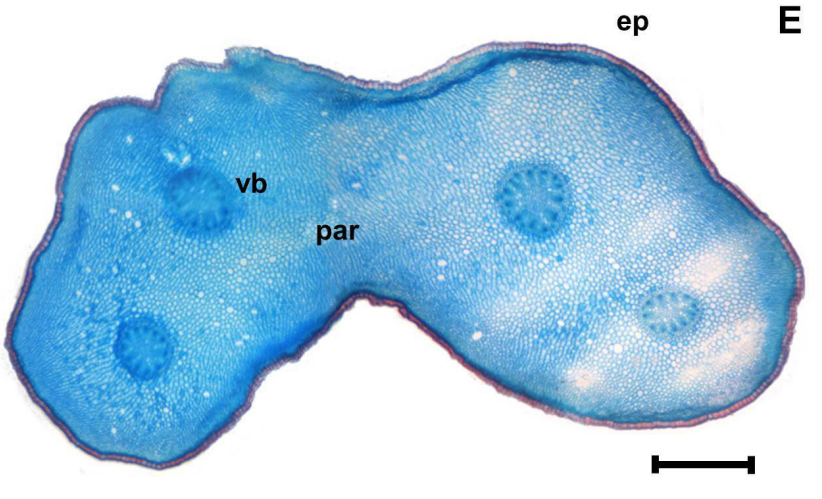

Figure 2. Origin and branching of adventitious roots in the apocole of Attalea microcarpa. A) cross-section of the apocole terminal region; B) detail of the adventitious root differentiation point; C) cross-sectional overview of the adventitious root; D) and E) cross-sections of branching of the adventitious root. cc: central cylinder, ep: epidermis, par: parenchyma, sc: sclerenchyma, vb: vascular bundle. Scale bars: $A, D=1000 \mu \mathrm{m} ; \mathrm{B}, \mathrm{C}, \mathrm{E}=500 \mu \mathrm{m}$. This figure is in color in the electronic version. 

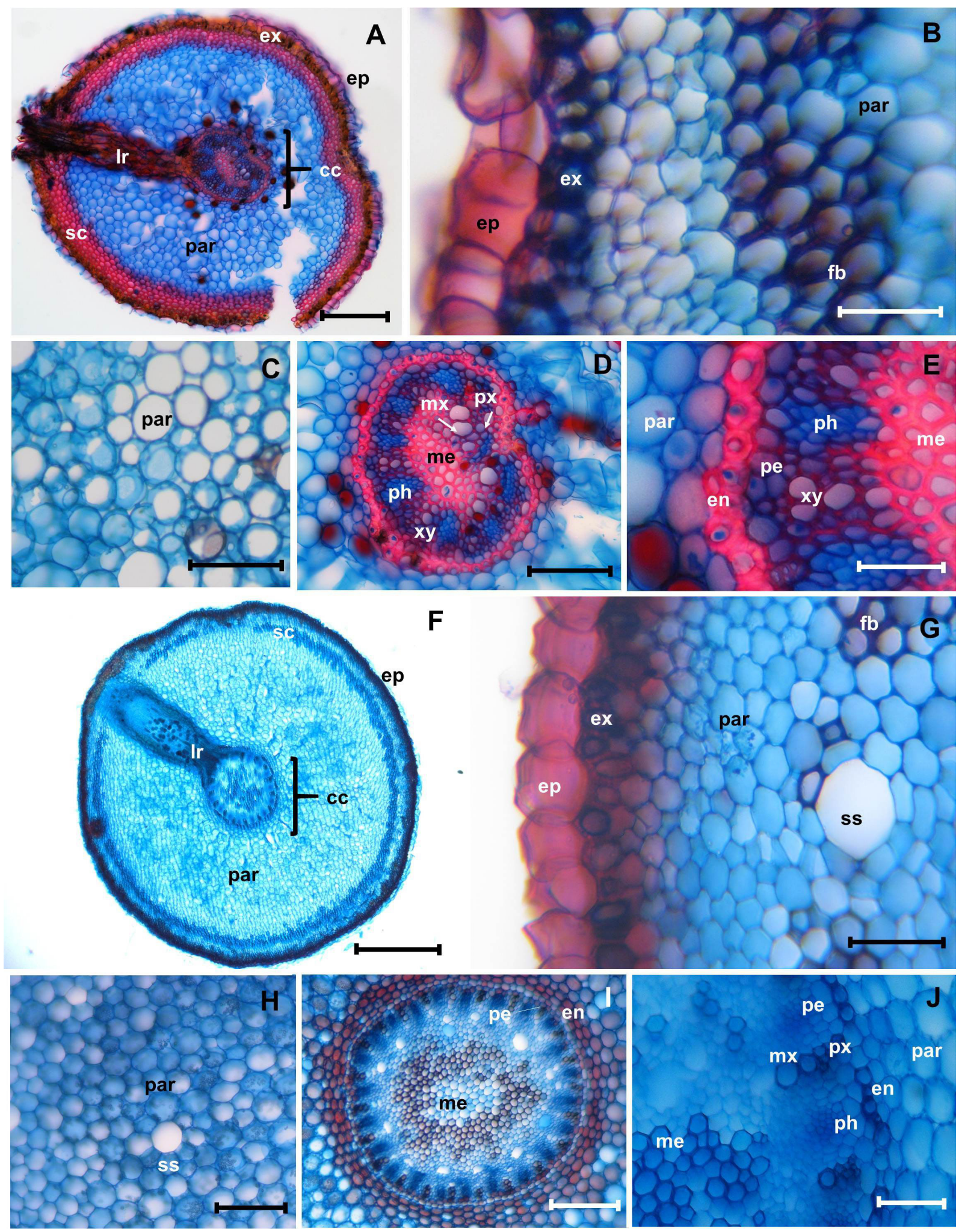

Figure 3. Comparison between the anatomical structure of the adventitious roots and the primary root of Attalea microcarpa. A-E: Adventitious root: A) general view in cross section; B) epidermis and external cortex; C) internal cortex; D) vascular cylinder; E) central cylinder detail. F-J: Primary root: F) general view in cross section; G) epidermis and external cortex; H) inner cortex; I) vascular cylinder; J) central cylinder detail. cc: central cylinder, en: endoderm, ep: epidermis, ex: exoderm, fb: fibers, Ir: lateral root, me: medulla, mx: metaxylem, par: parenchyma, pe: pericycle, ph: phloem, px: protoxylem, sc: sclerenchyma, ss: schizogenous space, xy: xylem. Scale bars: $A, F=500 \mu \mathrm{m} ; B, G, H, J=50 \mu \mathrm{m} ; C, D=100 \mu \mathrm{m} ; E=40 \mu \mathrm{m} ; \mathrm{I}=150 \mu \mathrm{m}$. This figure is in color in the electronic version. 
and metaxylem facing the center of the vascular cylinder (Figure $3 \mathrm{~d}, \mathrm{e})$. The primary root presents epidermis formed by papillose cells, sclerified exoderm, as well as the first layer of cells of the cortical parenchyma. The subepidermal cortex presents 3-4 rows of cells with secondary thickening forming a sclerified tissue (Figure 3f,g). Along the cortex, traces of cellular lysis occur, forming a few air spaces (Figure 3g), as well as cavities formed by schizogenous spaces in the outer and inner cortex (Figure $3 \mathrm{~g}, \mathrm{~h})$. The endoderm forms a ring circling the pericycle around the vascular bundles. The vascular system has up to 24 vascular bundles forming a circle (Figure 3i). As in the adventitious roots, the bundles occur with the xylem and phloem bands side by side forming a circle, with the protoxylem in the outermost regions and metaxylem facing the center of the cylinder (Figure 3j). The medulla is sclerified with the presence of schizogenous spaces. Mucilages were detected in the exoderm, in the external cortex and in the vascular bundles of both root types (Figure 4a-c). Starch grains were detected in the cortex of both roots (Figure $4 \mathrm{~d}, \mathrm{e})$. Protein bodies were detected in the external cortex and in the vascular bundles of both root types (Figure 4f-h).

The emission of adventitious roots from the apocole is different from that of lateral roots, which are emitted from the pericycle of primary roots (Esau 1974). The adventitious root of the apocole, and the primary root hold the basic anatomical structure of palm roots in the subfamily Arecoideae, including the occurrence of air spaces, frequent in roots of the group (Seubert 1998a,b). Subepidermal sclerified cells and a sclerified medulla have been described for the young roots of Euterpe oleracea Mart. (Paula 1975). A similar arrangement has been described in the aerial roots of Oenocarpus bataua Mart. (Orozco 2016). The same characteristics are observed in the subfamily Coryphoideae, as in Livistona rotundifolia (Lam.) Mart. (Viana et al. 2016). No secretions were detected in the schizogenous spaces in the present study, while these spaces of the cortex and medulla have been described as mucilaginous cavities for E. oleracea (Paula 1975). Root hairs occur in the apocole of $L$. rotundifolia (referred to as cotyledonary petiole in the study) (Viana et al. 2016). In Metroxylon sagu Rottb. the adventitious roots of the stem and lateral roots have the same anatomical pattern described in the present study for both roots, differentiating only in the sizes or numbers of layers of cells (Nitta et al. 2002). The abundant occurrence of mucilage in the external cortex of the root is a common character of tribe Attaleinae (Seubert 1998a). Individual mucilaginous cells can occur in the inner cortex and in the medulla of palm roots (Drabble 1904), as detected in the primary and adventitious roots in this study. Mucilages were found in other parts of palms, and this widespread occurrence seems to be common, as in the Aiphanes minima (Gaertn.) Burret stem (Tomlinson 2006) and in the leaves of four Oenocarpus species (Silva and Potiguara 2009). Starch is an important source of reserves already found in the embryo in some species of Arecaceae, such as Butia capitata (Mart.) Becc., which can be found in haustorium and apocole (Oliveira et al. 2013).
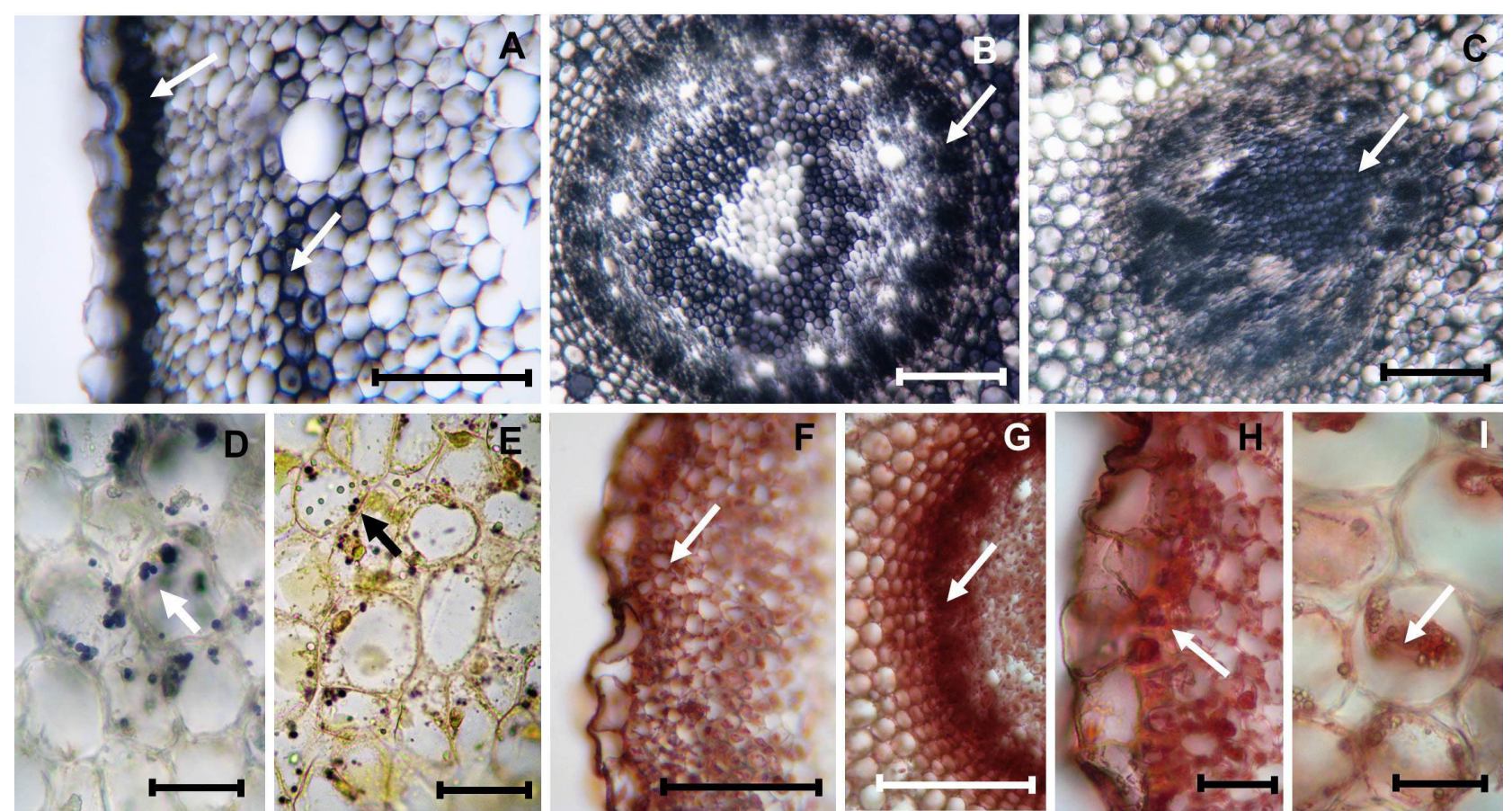

Figure 4. Histochemical tests for detection of mucilage in A) epidermis and B) vascular cylinder of the primary root, and C) adventitious root; starch in D) primary root and E) adventitious root; proteins in F) epidermis, outer cortex, and G) primary root vascular cylinder; proteins in $\mathrm{H}$ ) epidermis, outer cortex and I) adventitious root cortex. Scale bars: A, F, G = $100 \mu \mathrm{m} ; \mathrm{B}, \mathrm{C}=150 \mu \mathrm{m} ; \mathrm{D}, \mathrm{E}, \mathrm{I}=30 \mu \mathrm{m} ; \mathrm{H}=50 \mu \mathrm{m}$. Arrows indicate location of concentration of substances detected. This figure is in color in the electronic version. 
As the adventitious roots in A. microcarpa emerged from the apocole region, the starch found in these roots may be a useful source of resources for the seedling. Protein bodies can be located at various stages of initial development (Oliveira et al. 2013). No lipids were detected stored in the roots. The occurrence of neutral lipids in plants is associated with seed tissues where triacylglycerols stored inside lipid droplets serve as energy and carbon reserve during post-germination growth (Chapman et al. 2012). We suggest that the root emission in the apocole region is a morphological adaptation that favors the uptake of nutrients in environments such as campinarana (white-sand forests), in which A. microcarpa is frequent. It has been observed that, as soon as available, nutrients are absorbed by plants in campinarana through a dense and superficial root system, before the rain can carry the nutrients to the river systems (Oliveira 2001).

The morphoanatomical characters described in this study inform about the natural history of $A$. microcarpa. Morphoanatomy and histochemistry of the adventitious and primary roots present similar characteristics, leading to the conclusion that the structures originating from the apocole are in fact roots of non-orthodox origin, which may have an important role in enabling the species to occupy the environments in which it occurs. The processes related to the morphoanatomy and initial growth in this species should be further investigated due to their ecological and evolutionary importance.

\section{ACKNOWLEDGMENTS}

To Coordenação de Aperfeiçoamento de Pessoal de Nível Superior (CAPES) for granting a doctorate scholarship to the first author and a productivity scholarship to the third author, to the staff of the Laboratório de Botânica Agroflorestal (LABAF), for the support with infrastructure, and to Pedro Manoel dos Santos and Julia Simon Cardoso for the English translation.

\section{REFERENCES}

Balslev, H.; Grandez, C.; Zambrana, N.Y.P.; Møller, A.L.; Hansen, S.L. 2008. Palmas (Arecaceae) útiles en los alrededores de Iquitos, Amazonía Peruana. Revista Peruana de Biologia, 15: 121-132.

Bukatsch, F. 1972. Bemerkungen zur Doppelfärbung AstrablauSafranin. Mikrokosmos, 61: 255.

Chapman, K.D.; Dyer, J.M.; Mullen, R.T. 2012. Biogenesis and functions of lipid droplets in plants. Journal of Lipid Research, 53: $215-226$

Drabble, E. 1904. On the anatomy of the roots of palms. Transactions of the Linnean Society of London, 2: 427.

Esau, K. 1974. Anatomia das Plantas com Sementes. Edgard Blücher, Sáo Paulo, 293p.

Henderson, A. 1995. The palms of the Amazon. Oxford University Press, New York, 362p.
Kaiser, E. 1880. Verfahren zur herstellung einer tadellosen glyceringelatine. Botanisches Zentralblatt, 180: 25-26.

Kraus, J.E.; Arduin, M. 1997. Manual Básico de Métodos em Morfologia Vegetal. Editora Universidade Rural, Seropédica, 198p.

Karsten, H. 1856. Ueber die Bewurzelung der Palmen. Linnaea, 28: 601-608.

Lorenzi, H. 2010. Flora Brasileira: Arecaceae (palmeiras). Plantarum, Nova Odessa, 384p.

Melo, G.A.M.; Araújo, M.G.P.; Stauffer, F. 2017. Fruit development and histochemistry of Attalea microcarpa Mart. (ArecaceaeArecoideae). Flora, 235: 10-17.

Nitta, Y.; Goto, Y.; Kakuda, K.; Ehara, H.; Ando, H.; Yoshida, T.; Yamamoto, Y.; Matsuda, T.; Jong, F.S.; Hassan, A.H. 2002. Morphological and anatomical observations of adventitious and lateral roots of sago palms. Plant Production Science, 5: 139-145.

Oliveira, A.A.; Daly, D.C.; Vicentini, A.; Cohn-Haft, M. 2001 Florestas sobre areia: campinaranas e igapós. In: Oliveira, A.A.; Daly, D.C. (Ed.). Florestas do Rio Negro. Companhia das Letras, São Paulo, p.179-220.

Oliveira, N.C.C.; Lopes, P.S.N.; Ribeiro, L.M.; Mercadante-Simões, L.M.; Oliveira, L.A.A.; Silvério, L.O. 2013. Seed structure, germination, and reserve mobilization in Butia capitata (Arecaceae). Trees, 27: 1633-1645.

Orozco, L.I.G. 2016. Variaciones anatómicas en las raíces aéreas cortas de Oenocarpus bataua (Arecaceae). Rodriguésia, 67: 639-648.

Paula, J.E. 1975. Anatomia de Euterpe oleracea Mart. (Palmae da Amazônia). Acta Amazonica, 5: 265-278.

Seubert, E. 1997. Root anatomy of palms I: Coryphoideae. Flora, 192: 81-103.

Seubert, E. 1998a. Root anatomy of palms IV. Arecoideae, part 1 , General remarks and descriptions on the roots. Feddes Repertorium, 109: 89-127.

Seubert, E. 1998b. Root anatomy of palms IV. Arecoideae, part 2, Systematic implications. Feddes Repertorium, 109: 231-247.

Silva, R.J.F.; Potiguara, R.C.V. 2009. Substâncias ergásticas foliares de espécies amazônicas de Oenocarpus Mart. (Arecaceae): caracterização histoquímica e ultra-estrutural. Acta Amazonica, 39: 793-798.

Tillich, H.J. 2007. Seedling diversity and the homologies of seedling organs in the order Poales (Monocotyledons). Annals of Botany, 100: 1413-1429.

Tomlinson, P.B. 1990. The Structural Biology of Palms. Oxford University Press, New York, 477p.

Tomlinson, P.B. 2006. The uniqueness of palms. Botanical Journal of the Linnean Society, 151: 5-14.

Viana, F.A.P.; Costa, A.P.; Moro, F.V.; Pivetta, K.F.L. 2016. Morphoanatomical characterization of diaspores and seedlings of Livistona rotundifolia. Ornamental Horticulture, 22: 249-255.

RECEIVED: $15 / 12 / 2018$

ACCEPTED: 25/07/2019

ASSOCIATE EDITOR: Oscar Valverde 